\title{
DIMITRIS DALAKOGLOU
}

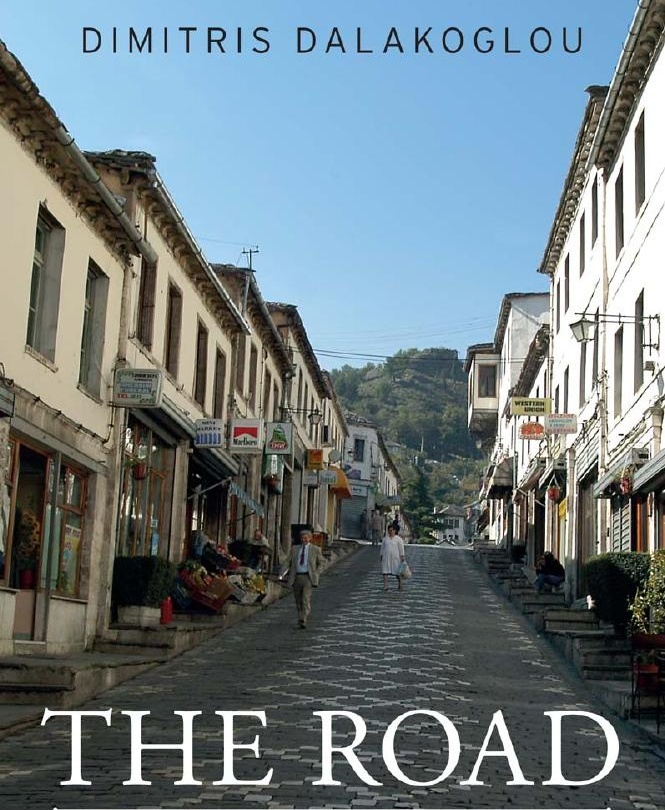

AN ETHNOGRAPHY OF (IM)MOBILITY, SPACE, AND CROSS-BORDER INFRASTRUCTURES INTHEBALKANS 


\section{The road}

\section{MANCHESTER \\ 1824}

Manchester University Press 
Dimitris Dalakoglou - 9781526109354 Downloaded from manchesterhive.com at 04/26/2023 11:38:03AM via free access 


\title{
The road
}

\section{An ethnography of (im)mobility, space, and cross-border infrastructures in the Balkans}

\author{
DIMITRIS DALAKOGLOU
}

Manchester University Press 
Copyright (C) Dimitris Dalakoglou 2017

The right of Dimitris Dalakoglou to be identified as the author of this work has been asserted by him in accordance with the Copyright, Designs and Patents Act 1988.

Published by Manchester University Press

Altrincham Street, Manchester M1 7JA, UK

www.manchesteruniversitypress.co.uk

British Library Cataloguing-in-Publication Data

A catalogue record for this book is available from the British Library

Library of Congress Cataloging-in-Publication Data applied for

ISBN 9781526109330 hardback

9781526109347 paperback

First published 2017

The publisher has no responsibility for the persistence or accuracy of URLs for external or any third-party internet websites referred to in this book, and does not guarantee that any content on such websites is, or will remain, accurate or appropriate.

Typeset in Sabon by

Koinonia, Manchester 